Thélème. Revista Complutense de Estudios Franceses

ISSN-e: 1989-8193

http://dx.doi.org/10.5209/THEL.52551

\title{
Indianos, exhibiciones etnológicas y freak shows en el teatro francés de la Tercera República
}

\author{
Ignacio Ramos Gay*
}

Recibido: 03/05/2016 / Aceptado: 27/02/17

Resumen. El objetivo de este artículo es establecer un paralelismo entre el personaje teatral del indiano y los aborígenes exhibidos en las barracas de feria durante el inicio de la Tercera República en Francia. Se tomará como corpus objeto de estudio el vodevil de Eugène Labiche, Le prix Martin (1876). Atendiendo a las similitudes físicas, morales y simbólicas que el rastacuero Hernandez presenta con los aborígenes protagonistas de freak shows y espectáculos de phénomènes coetáneos, se deducirá una crítica a la sociedad burguesa parisina definida por su rechazo de lo foráneo.

Palabras clave: Vodevil, Indiano, freak show, Eugène Labiche, Imperialismo.

\section{"Indianos", exhibitions ethnologiques et freak shows dans le théâtre français de la Troisième République}

Résumé. Le but de cet article est d'établir un parallélisme entre le personnage théâtral de 1' "indiano" et les aborigènes exhibés dans les baraques foraines au cours de la Troisième République en France. Le prix Martin (1876), d'Eugène Labiche, composera notre corpus objet d'étude. À partir des ressemblances physiques, morales et symboliques observées entre le rastaquouère Hernandez et les protagonistes des freak shows et des spectacles de "phénomènes" contemporains, on déduira une critique de la bourgeoisie parisienne définie par son rejet de l'étranger.

Mots clé : Vaudeville, Indiano, freak show, Eugène Labiche, Impérialisme.

\section{"Indianos", Ethnological Exhibitions and Freak Shows in French Third- Republic Theatre}

\begin{abstract}
The aim of this article is to trace the parallelisms between the theatrical character of the "Indiano" and the aborigines exhibited in fair barracks during the beginnings of the Third Republic in France. Through a close reading of Eugène Labiche's vaudeville, Le prix Martin (1876), I analyze the physical, moral and symbolic resemblances between the rastaquouère Hernandez and the natives featured in freak shows and other exhibitions of contemporary phénomènes. Such an approach will provide a critical perspective on the Parisian bourgeoisie that defined so much of itself through its rejection of foreign otherness. Key words: Vaudeville, Indiano, freak show, Eugène Labiche, Imperialism.
\end{abstract}

Cómo citar: Ramos Gay, I. (2017). "Indianos, exhibiciones etnológicas y freak shows en el teatro francés de la Tercera República". Thélème. Revista Complutense de Estudios Franceses, 32(1), 95-108.

\footnotetext{
* Universidad de Valencia.

ignacio.ramos@uv.es
} 
Una de las exhibiciones de mayor éxito durante la vida escénica del circo Barnum tanto en Estados Unidos cuanto en sus giras europeas fue aquella que exigía la participación del público para identificar y nombrar el cuerpo mostrado. Bajo el enigmático título de "What is it?" [¿Qué es esto?], Barnum suscitaba la curiosidad del espectador por medio de la exhibición de cuerpos humanos indescifrables, de difícil clasificación de acuerdo con las taxonomías raciales del momento, en una época dominada por el afán teratológico ${ }^{1}$ y la ordenación de morfologías corpóreas no normativas. Tan sólo tres meses más tarde de la publicación de la obra científica que revolucionaría el espectáculo parateatral del cuerpo abyecto, el Origin of the Species de Darwin (1859), P. T. Barnum aprovechaba la conjunción entre pseudociencia y show business presente en la exhibición de cuerpos humanos de seres vivos inclasificables, desafiantes no sólo de los freak shows popularizados a lo largo de la primera mitad del 19 e incluidos en barracas de feria, museos, exposiciones universales y $\operatorname{circos}^{2}$, sino de toda una epistemología antropológica que ejercía al mismo tiempo de coartada científica y de acicate mediático para el espectador. Con la exposición de individuos de tez oscura y tamaño variable, primitivos en apariencia respecto del público occidental, caracterizados y animalizados por medio de pieles e instrumentos de caza primarios, y cuyos misteriosos orígenes impedían que se les relacionara con ninguna de los ramas étnicas conocidas hasta el momento, Barnum proporcionaba un espectáculo que superaba el carácter enigmático de las exhibiciones etnológicas típicas de ferias y exposiciones universales sugiriendo la visualización y prueba de la hipótesis formulada por Darwin en su obra: el missing link. Como el "eslabón perdido" darwiniano, los individuos presentados eran para el observador de la segunda mitad del XIX, seres transicionales, inexistentes en el registro científico del momento o, de acuerdo con los panfletos que servían de reclamo de la atracción, sencillamente "indescriptibles". En palabras del propio empresario, individuos como aquel que fue expuesto en el American Museum eran "neither a man nor monkey, a creature demonstrating characteristics animal as well as human, civilized as well as brutish" (Cook, 1996: 140). La exhibición de Barnum proyectaba lo que se denominaba un "nondescript" (Cook, 1996: 140): una "curiosidad viviente", un ser liminal que ponía contra las cuerdas los conocimientos antropológicos del momento, y que entroncaba con toda una tradición creada en torno al "homo ferus". Además, la originalidad de Barnum se completaba con la invitación lanzada al público en el intento de contribuir a la definición de lo mostrado, a expandir con su esfuerzo intelectual las fronteras del cono-

La modernidad clínica hizo que el carácter proteico de la abyección fuera cada vez menos resultado de la superstición que de las diferentes patologías médicas, tal y como estableció la obra cumbre de la teratología decimonónica, la Histoire générale et particulière des anomalies de l'organisation chez l'homme et les animaux (1832) de Isidore Geoffroy Saint-Hilaire. Por medio de la clasificación de toda anomalía corporal, el ensayo de Saint-Hilaire rompía con el discurso de siglos precedentes y establecía que las deformaciones humanas y animales no eran resultado de un libre arbitrio natural o de la superstición divina, sino de causas biológicas que podían ser detectadas y explicadas clínicamente. Su trabajo consolidaba la clasificación científica del humano a través del cuerpo, y más concretamente, a través de sus deformaciones físicas, derivándose una concepción de norma morfológica a partir de la exención a dicha clasificación. A este respecto, véase Snigurowicz (2005).

2 Sobre los espectáculos exóticos llevados a cabo en el marco de las Exposiciones Universales celebradas en París, véase Besnier (2010: 256-257). 
cimiento, añadiendo de este modo un grado de participación directa de aquél en el debate científico de la época.

Es evidente que el empresario aprovechó el escenario del circo y el tirón mediático del evolucionismo para crear un espectáculo que mezclaba cientificidad y voyeurismo. Con ello, Barnum no hacía sino seguir la tendencia social de la segunda mitad del siglo por regularizar lo diferente. Desde el plano antropológico, como afirma Suzanne Scholz (2013: 80), la proyección del cuerpo abyecto representaba uno de los mecanismos de reafirmación de un espectador corpóreamente normativo, cuya normalidad - es decir, aquello que establece una norma - era reforzada por la visión de lo extraño. Desde un punto de vista postcolonial, la presentación de fisonomías pertenecientes a etnias geográficamente lejanas confirmaba el imperialismo cultural eurocentrista, aunándolo con los presupuestos científicos popularizados por las tesis de Darwin, de modo a consolidar el liderazgo de las sociedades occidentales en la jerarquía de civilizaciones. Así, el espectáculo de "What is it?" surgía en la estela de muchas otras exhibiciones etnológicas que, bajo un prisma de interés educativo, recurrían al exotismo antropológico para mostrar individuos pertenecientes a territorios ignotos ante un público occidental guiado por los usos y costumbres de la burguesía, consolidando lo que Leslie Fiedler (1996) bautizaría como la "tiranía de lo normal".

Si bien esta tipología de espectáculos que Lindfors (1999) reagrupa bajo la denominación de "ethnological showbusiness" se remontaba al siglo XVI y a épocas marcadas en gran medida por los avances en materia de navegación y circulación marítima, el principal referente decimonónico fue la exhibición de la "Venus de Hottentot" en $1810^{3}$, sirviendo de punto de partida a una puesta en escena de culturas arcaicas y pueblos subdesarrollados que confirmaba la superioridad cultural del observador. Redescubiertos como producto comercial a través de las campañas militares de Francia y Gran Bretaña en diferentes continentes, y puestos en el punto de mira científica a través de la creación de diversas sociedades etnológicas cuyo objetivo era tanto identificar cuanto aportar explicaciones antropológicas a la diferencia racial, el espectáculo etnológico incluía desde zulús y bosquimanos africanos hasta inuits pertenecientes a poblados esquimales de América y Groenlandia, pasando por nativos norteamericanos (wyandots, ojibwas, iroqueses), aborígenes australianos, maorís neozelandeses, lapones noruegos, "liliputienses" aztecas, botocudos brasileños, o habitantes de Tierra del Fuego, entre muchos otros pueblos exóticos cuya exhibición -acompañada de una escenografía que simulaba sus modos de vida y costumbres- además de alentar el interés por lo diferente, distante y desconocido, constituía el catalizador del espíritu expansionista europeo, ratificando el progreso occidental respecto de pueblos menos desarrollados tecnológicamente, y demostrando con ello las "virtudes" culturales de la civilización occidental.

En términos coloniales, Nadja Durbach afirma que la exhibición etnológica del siglo XIX establecía una clara compartimentación binaria entre la supremacía cultural occidental articulada en torno al cuerpo blanco, sano y vinculado a la burguesía en tanto que morfología corpórea más evolucionada, frente a su antagonista, el

Perteneciente a la tribu africana de los khoi khoi, y debido a su excesiva esteatopigia, Saartjie (Sarah) Baartman fue rebautizada como la "Venus de Hottentot" tras ser expuesta en casetas de circo de París y Londres durante el primer tercio del siglo XIX por Henrick Caesar. Sobre su exhibición en Europa, véase Strother (1999). 
salvaje de tez oscura, cuya fisonomía representaba una proyección de su regresión y anacronismo cultural (Durbach, 2010: 149). En no pocas ocasiones, la exhibición etnológica lindaba con el freak show por cuanto éste último llevaba dicha oposición hasta sus últimas consecuencias al mostrar cuerpos de hombres completamente animalizados o, como pretendía Barnum, "indescribibles" debido a su naturaleza ignota. A lo largo de las décadas de 1860 y 1870, los ejemplos de seres que desafiaban las clasificaciones etnológicas establecidas proliferaron en Francia y en Gran Bretaña. Durbach ilustra lo anterior citando a una joven de catorce años exhibida en París en 1870 y afectada por hipertricosis y microcefalia congénitas, a la que sus contemporáneos denominaron "Darwin's Missing Link" (Durbach, 2010: 93). También por su naturaleza hirsuta, la mexicana Julia Pastrana reunió diversos apelativos que acentuaban su hibridismo -desde la "mujer gorila" o la "mujer babuina", hasta la "mujer oso"- en exhibiciones que trascendieron sus propios años de vida, al ser embalsamada en Moscú en 1860, y visitar una vez muerta las principales capitales mundiales en compañía de su también fallecido hijo. La década de 1880 contempló nuevamente la encarnación del "eslabón perdido" darwiniano con la exhibición de la niña Krao, procedente de Indochina, que recorrió toda Europa de la mano del empresario canadiense G. A. Farini, quien justificaba su parentesco con los primeros simios debido al exceso de vello por todo su cuerpo, recubriendo el espectáculo en un lenguaje pseudocientífico que pretendía sumarse -cuando no plasmar visualmente ante el espectador- la veracidad de las teorías evolucionistas. Todas estas exhibiciones contribuyeron a forjar un imaginario colectivo de lo etnológicamente extraño, a menudo alentado por un complejo entramado mediático propio de la industria cultural del espectáculo que se consolidaba en el momento (fotografías, grabados, ilustraciones en la prensa, relatos de captura, etc.) y que acentuaba -no en pocas ocasiones, falazmente- sus rasgos animalizados.

Este rasgo fue fundamental en la exhibición de los llamados "últimos aztecas", los hermanos microcefálicos Maximo y Bartola, publicitados entre 1850 y 1900 en diversas Exposiciones Universales parisinas como los postreros legatarios de una extinta raza centroamericana originaria -dependiendo de los panfletos que anunciaban su visita- bien del Yucatán, bien de Guatemala. Apodados también los "aztecas liliputienses" o los "hijos de Iximaya", en referencia a sus corporeidades anormativas propias de territorios remotos cuando no directamente de la ficción literaria, su éxito en Europa se debió a la habilidad con que el empresario Ramón Selva supo aglutinar en el espectáculo a toda la comunidad científica del momento tanto en América cuanto en Francia e Inglaterra, suscitando un interés que les condujo incluso en ser presentados ante el emperador Napoleón y su familia, entre otros muchos dignatarios europeos ${ }^{4}$. Durante la exhibición, los hermanos eran presentados como ejemplos vivientes de una civilización desaparecida, recuerdos carnales de un tiempo pasado, que alcanzaban gracias a las tablas de Barnum el privilegio de convertirse en muestras museísticas perfectamente conservadas que cobraban vida durante la representación, brindando con ello al público un testimonio único de sus propios ancestros en la cadena evolutiva, tal y como habían sido formulados por Darwin ${ }^{5}$.

Sobre las giras de los dos hermanos en Europa, así como sobre sus orígenes centroamericanos, véase Bogdan (1990: 127-134).

5 Respecto de la consideración de Maximo y Bartola en tanto que plasmaciones de la teoría darwiniana, véase Rothfels (1996: 158-172). 
En el marco de esta polarización cultural del individuo procedente de otros continentes, el advenimiento del indígena como personaje teatral se embebe de los atributos distintivos popularizados por las exhibiciones señaladas anteriormente, estableciendo una frontera entre el observador y el observado. Más aún en el caso de un género como el vodevil parisino, dominado esencialmente por la cultura burguesa del Segundo Imperio, que abarca tanto los orígenes sociales de sus propios creadores hasta los del público, las salas de representación, o los personajes y temas puestos en escena ${ }^{6}$. La presencia de personajes originarios de latitudes hispanoamericanas está marcada no sólo por el filtro cómico que define al género, sino, sobre todo, por los espectáculos paralelos populares coetáneos como el freak show y la barraca de feria, de corte más popular, pero igualmente frecuentados por la burguesía. Como veremos en las páginas que siguen, la construcción del personaje del indiano en una obra clave de la estética teatral burguesa del Segundo Imperio francés y primeros años de la Tercera República, el vodevil de Eugène Labiche y Émile Augier, Le Prix Martin (1876), recoge con exactitud los diacríticos culturales establecidos por la exhibición etnológica, estableciendo transferencias con respecto a este espectáculo análogo, y puliendo elementos sustancialmente populares en aras del decoro vodevílico. En otras palabras, el vodevil traslada a tablas más nobles los estereotipos culturales establecidos por la caseta de feria, construyendo la figura del indiano en tanto que traslación del personaje tribal y extraño exhibido en ella, y reforzando de este modo el antagonismo entre las culturas amerindias y la burguesía imperial francesa, el cisma entre dos civilizaciones, y la supuesta superioridad occidental respecto de las culturas consideradas primitivas durante el último tercio del siglo XIX.

Como es bien sabido, la figura del indiano no es nueva en el teatro europeo. La dramaturgia aurisecular retrata con frecuencia el viaje a Indias en busca de riquezas, particularmente Lope de Vega en La moza de cántaro (1618) y La noche de San Juan (1631), o Calderón en Guárdate del agua mansa (1657) ${ }^{7}$. En Francia, el personaje es igualmente popular a lo largo de la segunda mitad del siglo XIX, como atestigua el éxito de las operetas de Meilhac y Halévy, con música de Jacques Offenbach, Le Brésilien (1863) y La vie parisienne (1866), que consagran el éxito económico, cultural y estético de la burguesía del Segundo Imperio a través del personaje del "Brésilien". A diferencia de los matices peyorativos observables en el teatro español del Siglo de Oro y vinculados a la ambición desmedida y el expolio colonial, el "Brasileño" de Meilhac y Halévy representa el paradigma del éxito personal fundamentado en el enriquecimiento y los placeres mundanos. La ciudad de París lo acoge por cuanto su nuevo estatus casa bien con una sociedad construida en torno a la imagen pública vehiculada por el poder adquisitivo, como demuestran los versos con los que se presenta al público en La vie parisienne: "Je suis Brésilien, j'ai de l'or, / Et j'arrive de Rio-Janeire / Vingt fois plus riche que naguère, / Paris, je te reviens encor!" (Meilhac y Halévy 1867: 17). El personaje es igualmente sinónimo de arribismo al asociarse a tantos parisinos enriquecidos en Sudamérica y regresa-

6 Brigitte Brunet (2009: 14-24) utiliza la metáfora del "escenario espejo" de Diderot para definir un género que se quiere el reflejo de su público y de sus autores. El Palais-Royal, sala donde se estrena la obra de Labiche y Augier que ocupa este estudio, se consideró, junto al Théâtre du Vaudeville, el bastión del género.

7 Sobre el indiano en el teatro español del Siglo de Oro, véase, entre otros, Martínez Tolentino (1991) y Brioso Santos (1998 y 2001). 
dos a París una vez hecha fortuna; fortuna a menudo exhibida sin gusto en el seno de una burguesía jactanciosa que multiplica los diacríticos visuales con el fin de establecer fronteras con los recién llegados a una clase que se reivindica en torno a la geografía de la capital. Prueba de este desprecio es el término que identificaba genéricamente al indiano: "rastaquouère". Su equivalente en castellano, "rastacuero", procede del francés, si bien éste último, a su vez, deriva de un venezolanismo 8 cuyo significado es "fanfarronear", formado a partir de una hibridación léxica de un verbo y un sustantivo españoles ("arrastra cuero"), que remitía a los curtidores de piel sudamericanos o "rastacueros", enriquecidos por sus negocios, y decididos a conquistar la capital mundial del placer y del lujo. Con el término, la burguesía parisina lograba crear una frontera cultural que trascendía la mera cantidad de bienes poseídos, señalando al arribista como otredad anómala en el seno de una sociedad fundada en la ostensión visual. Fueron precisamente las operetas de Meilhac y Halévy las que popularizaon la imagen del "rastaquouère" en Francia, gracias en gran medida a la encarnación que del mismo llevó a cabo el celebérrimo actor Jules Brasseur. Según Gaston Jollivet (1927: 80), la noche de estreno de Le Brésilien, Brasseur, en la piel de un falso brasileño - por cuanto resultaba una imitación de un personaje francés en la obra, el poetastro Greluche- de nombre "Acapulco", lanzaba al público el famoso triunvirato onomatopéyico paródico, "astaquer, bonastaquer, rastaquère", imitativo del habla quebradiza del extranjero, con marcada pronunciación cómica de la vibrante "r" y la oclusiva "q", que daría lugar a una queja de ciudadanos brasileños formalizada ante el Ministerio de Asuntos Exteriores. El éxito del personaje originó un sinfín de grabados y caricaturas en la prensa, así como una legión de descendientes teatrales que, progresivamente, fueron dotando al personaje con rasgos cada vez más cómicos, articulados en torno a un habla quebradiza y taraceada de interjecciones españolas ${ }^{9}$.

A la vista de estos precedentes, es posible afirmar que, aunque con matices y recursos cómicos diferentes, todos ellos poseen un denominador común: la construcción teatral del indiano resulta ante todo reflejo de los prejuicios y arquetipos culturales burgueses creados para diferenciarlo en el seno de la sociedad en la que se integra, con el fin de fomentar la distancia cultural entre ambos por medio de la acentuación de los rasgos primitivistas que lo vinculan a la exhibición de salvajes propia de espectáculos como la exhibición etnológica. El indiano como otredad cultural traduce el carácter normativo de la mirada burguesa respecto de los propios atributos que la conforman, y es la prueba viviente de lo salvaje como potencialmente conquistable y domesticable de acuerdo con los usos culturales occidentales. Este aspecto es tanto más reseñable por cuanto el personaje siempre fue encarnado por un actor francés que imitaba y caracterizaba al indiano de acuerdo con el imaginario cultural del momento. Al igual que tantos otros espectáculos etnológicos en que el aborigen no era representado por un genuino miembro autóctono de una tribu particular ${ }^{10}$, la figuración del

Sobre la etimología del término, véase Gobello (2005).

La figura del indiano teatral en Francia es prolongada y popularizada por Georges Feydeau, a través del personaje del Général Irriga en Un fil à la patte (1894). Feydeau perpetua y acentúa los rasgos propuestos por Labiche, estableciendo un paradigma del "rastaquouère" como personaje de habla fragmentaria y reducida a exabruptos.

10 Es el caso del zulú africano exhibido en Gran Bretaña, donde en más de una ocasión se trataba de irlandeses encarnando a aborígenes, por cuanto ambos eran reunidos por la ideología imperial británica. A este respecto, véase Durbach (2010: 165-170). 
indiano estaba manufacturada exclusivamente para su exhibición teatral, atendiendo al criterio del público receptor de la obra, y ahondando en el entendimiento que el público poseía del mismo.

Los autores se hacen eco del personaje popularizado por las obras de Meilhac y Halévy enriqueciéndolo por medio de atributos presentes en las exhibiciones etnológicas y espectáculos feriales con los que cohabitan en el espectro teatral parisino. En Le prix Martin, el personaje de Hernandez Martinez [sic] representa al pariente enriquecido procedente de Centroamérica, de visita en el hogar de su primo Martin, en París. Éste último es víctima de una infidelidad por parte de su esposa Loïsa y su mejor amigo, Agénor. El indiano descubre la trama oculta, y tras hacer público el secreto, exige, a pesar de las reticencias de su primo, una sangrienta venganza en nombre del honor a la familia. En un último acto de notables ambigüedades, Martin opta por renunciar tanto a la venganza cuanto a su esposa -seducida por un apasionado Hernandez- y, en su lugar, reanudar su amistad con Agénor, sentados, solos, al cierre del telón, en torno a una mesa de juego. Como veremos en las páginas que siguen, el "rastaquouère" de Labiche y Augier -encarnado el día de su estreno, en un guiño a la obra de Meilhac y Halévy, también por el propio Brasseur- constituye un retrato más complejo que aquel de Offenbach por cuanto agudiza el antagonismo entre Europa y América a través de una caracterización del personaje similar a los aztecas, zulús y demás aborígenes exóticos propios de espectáculo etnológico, sirviendo todos ellos de testimonio del primitivismo cultural amerindio, del declive de razas preconizado por los baluartes científicos del momento, y del progreso eurocentrista.

Con el fin de marcar la diferencia entre el rastacuero arribista y el burgués parisino auténtico, asimilados por el denominador común crematístico, Labiche y Augier inciden en la especificidad geográfica del personaje, su procedencia desde reinos lejanos, ahondando así en su exótica etnicidad por medio de una serie de perífrasis que lo sitúan en el exterior de la nueva sociedad que lo acoge. Sus raíces españolas lo identifican ya desde el nombre mismo, "Hernandez Martinez", dos apellidos comunes que, al margen de conformar una rima consonante que genera una melodía cómica, remiten en el imaginario francés a los conquistadores españoles más celebérrimos. Mostrando la ignorancia burguesa que aglutina bajo un mismo idioma diversas nacionalidades, pero también la dificultad por parte del parisino de definir los orígenes de un personaje que considera un salvaje - si no es por aquello que permite aculturarlo, esto es, el patronímico que señala su linaje y descendencia colonial -el rastacuero se convierte al mismo tiempo en metonimia del español "Voilà un Espagnol qui m'ennuie!", exclama su propio primo (Labiche, 1992 [1876]: 812)- y del sudamericano, ligando ambas geografías en virtud de un pasado colonial que es recuperado y trasladado al presente imperial francés.

Si los apellidos del rastacuero denotan su ascendencia española, su nombre lo asocia a los territorios conquistados en el siglo XVI y XVII, estableciendo de este modo un puente con tantas otras tribus expuestas en las casetas de feria. Según indica el autor por medio del personaje de su primo, no hay que olvidar que, tras su regreso a Francia, la rama familiar del propio Martin renunció a su apellido original, "Martínez", en un intento de desligarse del salvajismo implícito en él, y de refinarse de acuerdo con el nuevo espacio que lo acogía: "dire que, si ma famille n'avait pas quitté le Guatemala, je m'appellerais Hernandez Martinez comme mon cousin" (Labiche, 1992 [1876]: 812). El contraste entre el enclave burgués y la presencia del 
bronco Hernandez, la integración del asilvestrado en un espacio codificado de acuerdo con el decoro de las clases medias, es notorio a medida que avanza la obra, y los propios personajes lo evidencian estableciendo oximorones que remiten al mestizaje entre culturas arcaicas y otras más avanzadas. "Quel sauvage?", pregunta Loïsa, a lo que Pionceux responde "Le cousin de Monsieur" (Labiche, 1992 [1876]: 773). "C'est un grand seigneur, ce sauvage-là", reprende Martin al mayordomo (Labiche, 1992 [1876]: 765). La antítesis léxica refuerza el maridaje sanguíneo y el extrañamiento que produce su presencia en el entorno burgués, implosionando los códigos establecidos y apuntando al rastacuero como elemento desestabilizador del protocolo nominativo que sirve de referencia a la cultura imperial.

Hernandez está asociado a las culturas amerindias tras su matrimonio con la reina del poblado Chichimeco. Esta denominación, que remite de manera genérica a todos los pueblos situados al norte de los antiguos territorios aztecas, coincide con los orígenes de los dos indígenas popularizados por Barnum a lo largo de la segunda mitad del XIX en toda Europa, y que fueron exhibidos a menudo en el Jardin des Plantes de París, al que el propio dramaturgo alude en numerosas ocasiones como metonimia de este tipo de espectáculos ${ }^{11}$. Si el término "Chichimeco" utilizado para definirlos posee en sí mismo, para el público parisino, resonancias cómicas y bizarras, dando lugar a chistes por parte de quienes lo pronuncian ("Tu croix aux Chichimèques, toi?”, pregunta Agénor (Labiche, 1992 [1876]: 766), éste no evidencia más que la extrañeza que rezuman ante el observador de la capital francesa que, en un ejemplo más de su desconocimiento de todo cuanto transciende el margen urbano dominado por él mismo, llega a confundirlos con un culto religioso. En este sentido, son los mismos autores quienes especifican la conexión entre el indiano y las exhibiciones etnológicas al explicar, por boca de Martin, que "c'est une tribu d'Indiens dans l'Amérique centrale. Tu ne crois plus à la géographie! Malte brun?" (Labiche, 1992 [1876]: 766). Incluso, más adelante, apuntarán hacia sus orígenes feriales y circenses al definirlo, a través de Edmond, como "un athlète qui court les foires" (Labiche, 1992 [1876]: 788). La referencia a los atletas feriales no es casual. Con ella, los dramaturgos evidencian su profundo conocimiento de las alternativas parateatrales de su época y, en particular, del contexto del teatro de feria, que era precisamente aquel que acogía a los "atletas", "colosos"12 e indígenas de otras latitudes cuyo exotismo residía en corporeidades anómalas características del tribalismo primitivo que la sociedad imperial trataba de taxonomizar y repertoriar.

Los autores, además, emparejan el vaudeville con las exhibiciones etnológicas de la segunda mitad de siglo por medio de la fuerza escénica que traduce la morfología corporal y lingüística de Hernández. Si en el imaginario teatral del espectador parisino el personaje remite, por su fisonomía y potencia física, tanto a nativos de otras latitudes como a los atletas de feria mencionados por Edmond, esto se debe a que unos y otros coinciden en la proyección de una corporeidad, abyecta, fuera de lo común, capaz de generar una mezcla de miedo, comicidad y fascinación. El india-

11 El parisino "Jardin des plantes" es evocado en otras obras del autor como Doit-on le dire? (1872) o Le plus heureux des trois (1870). El jardín integraba el Museo de Historia Natural, formado por diversos invernaderos botánicos, un zoológico, museos de mineralogía y geología, completándose con secciones dedicadas a la anatomía comparada. El Jardin des Plantes se convertía en un compendio de todas las especies animales, minerales y vegetales identificadas en Francia.

12 Sobre los colosos de feria en París, véase Pajot (2003: 159-167). 
no de Labiche es ante todo expresión de potencia del cuerpo. Su presencia teatral es vehiculada por su figura, que se reivindica con violencia frente a las constricciones de la etiqueta burguesa. Como el indígena del freak show, lo primero que le distingue es su ostensibilidad corporal. Hernandez es desbordamiento gestual y dinamismo escénico. El resto de personajes que lo asisten insisten en señalar sus arranques violentos y la rapidez con la que se entrega a peleas y tumultos, aunándolo con culturas en las que la agresión física forma parte de un ritual de sometimiento del otro. De gatillo fácil, la dialéctica lingüística no forma parte de sus planes cuando entra en conflicto con otros personajes, cuya resolución pasa siempre por la embestida y el ataque ("Caramba! Veux tu que je l'étrangle?", exclama a su primo, al enterarse de la deslealtad de su amigo (Labiche, 1992 [1876]: 779). El indiano, como los indígenas exhibidos en el Jardin des Plantes, se reduce a la fuerza del cuerpo como masa escénica.

Filtradas por el prisma cómico del vodevil, la mezcla de sensaciones basculantes entre la irrisión y el pavor producidas por la exhibición de lo extraño es profundamente reforzada por el habla del personaje. El indiano de Labiche y Augier posee un habla tan hiperbólica y desbordante como su propio cuerpo. El elemento identificador de mayor calado en el imaginario colectivo del personaje son las interjecciones en español que salpican su discurso. Hernández arma su violencia verbal por medio de una batería de impresiones súbitas enfatizadas por los "caraï!", “caramba!”, “demonio!” y “válgame Dios!” (Labiche, 1992 [1876]: 776, 777, 789) con los que riega sus violentas emociones. Independientemente de su carga semántica, y de la relativa comprensión de la misma por parte del público parisino, el indiano recurre al español como grito de guerra frente al carácter normativo comunicacional del francés. El español del rastacuero es utilizado como jerga incomprensible por el autor respecto del espectador que desconoce su significado, al tiempo que como recurso cómico para aquel que sí lo consigue desgranar. En ambos casos, debido a la proliferación de sus alaridos, el habla desbordante del "arrastra cueros" lo reconcilia con los gritos inarticulados de tribus indígenas. De hecho, los propios personajes así lo identifican, al entender que el chillido de Hernandez es propio de latitudes más cálidas, evidenciando su patria de adopción: "tu as rapporté des pays chauds une terrible habitude... Tu cries comme un sourd!" (Labiche, 1992 [1876]: 787).

Los gritos en español del indiano desnaturalizan su humanidad, asimilándolo al lenguaje de los animales, y despojándolo de cualquier rastro de humanidad hasta convertirlo en una otredad transicional, a mitad camino entre lo humano y lo animal. Esta animalización se completa por medio de una irrefrenable pulsión sexual, primitiva y asocial, que lo reconciliaría con sus raíces selváticas estudiadas hasta ahora, y con aquellas mostradas por los "eslabones perdidos" de las ferias. Como tantos otros especímenes expuestos a la mirada de curiosos, los cuerpos indígenas anómalos rezumaban para los espectadores una sexualidad impetuosa que los retrotraía a formas anteriores de la escala evolutiva, precisamente por medio de la exhibición de su desnudez, y del vínculo que, gracias a ella, establecían con otras especies animales. La propia naturaleza liminal de estos era confirmada por el hibridismo de su nombre, que ejercía de reclamo ("mujer oso", "mujer tigre", "hombre elefante", etc.) en una época dominada por la conceptualización del hombre como entidad más cercana del mono que de los ángeles, tal y como era argumentado por los seguidores de Darwin a principios de la década de 1870, fecha de publicación de The Des- 
cent of Man (1871) ${ }^{13}$. La animalización nominal de este tipo de especímenes resultaba clave para certificar su crisol genético y para tender un puente hacia formas menos evolucionadas que las de los humanos de acuerdo con las teorías darwinianas. Además, su carácter híbrido se fundamentaba en la mayoría de los casos en un ostensible y descontrolado apetito sexual, no sometido a la moral convencional del espectador.

El vodevil de Labiche y Augier recoge con exactitud esta misma sexualidad primitiva del indiano. El rastacuero segrega una lujuria incestuosa para con la esposa de su primo que transgrede cualquier canon amoroso tradicional, confirmando así su indómita animalidad. También los aztecas Maximo y Bartola fueron presentados en las ferias como hermanos incestuosos por haber contraído matrimonio entre sí, de acuerdo no ya con un rito indígena, sino en Londres, en una ceremonia civil ${ }^{14}$. Como ellos, Hernandez niega la exogamia. En tanto que potencia física escénica, y a pesar de emplear un discurso galante trasnochado y espurio, el indiano carece de la menor contención, guiándose por incontenibles impulsos sexuales. De ahí que la visión de la pierna de Loïsa -a la que no duda en llamar "prima"- le haga "lanzar fuego por la nariz" (Labiche, 1992 [1876]: 784), y que su tendencia exhibicionista priorice la visualización del cuerpo como mecanismo erótico.

Resulta inevitable asociar esta tendencia a teatralizar el cuerpo del indiano como fisonomía animal con los movimientos a favor de la eugenesia que comienzan a desarrollarse en la década de 1840-1860 en Francia, y de los que es coetáneo Labiche. Desarrollada por Francis Galton, e impulsada por la emergencia de la disciplina de la estadística, la eugenesia establece que la raza puede ser mejorada por medio de prácticas selectivas de cría cuyo fin es la reproducción de los miembros más fuertes de la especie, sirviendo a diversos países como prevención científica de la clases medias contra los "peligros biológicos" de la inmigración. El indiano, a pesar de su fortaleza física y de su poder adquisitivo, es señalado como diferente e inadaptado. En un esfuerzo por aplicar una política de higiene pública velada bajo el prisma cómico, Hernandez traduce la amenaza y el miedo de una clase social de ver adulterada y debilitada su esencia al ser mezclada con la otredad, estableciendo ecuaciones identitarias por las que todo cruce del hombre blanco con otras etnias abocaba, en último término, a la destrucción de aquél (Fahy, 2006: 25).

Si la primitiva sexualidad del indiano actúa como catalizador público del involucionismo de las especies, ésta planea igualmente en su articulación social desde un punto de vista político. El indiano, en tanto que salvaje para la burguesía parisina, es culturalmente regresivo no sólo por su comportamiento sexual sino también por su modo de organización en sociedad. Defensor de una burguesía que ejerce su poder como grupo de presión por medio de la participación directa trasladada por el voto, Labiche y Augier caracterizan el estancamiento cultural de los indígenas a través de su tribalismo feudal, más propio del Antiguo Régimen desbancado por la

13 Fecha en la que el nombre de Darwin queda indefectiblemente ligado a la "ape theory", como atestiguan las numerosas caricaturas del científico, bien acompañado por un mono, bien transmutado él mismo en primate, proliferaron en la prensa popular del momento. Sobre la relación entre Darwin y las ilustraciones decimonónicas, véase Smith (2009).

14 Fiedler (1993: 45); Bogdan (1990: 131) apunta a cómo el matrimonio fue en sí mismo un controvertido acicate de cara al público para suscitar su interés debido precisamente a la naturaleza incestuosa del mismo. 
clase burguesa. Hernandez es objeto de comicidad para el público francés por el hecho de coronarse rey de una cultura primitiva a través del matrimonio con la reina de los Chichimecos, renunciando súbitamente a su credo republicano ("J'ai toujours été républicain mais un trône, ça ne se refuse pas" (Labiche, 1992 [1876]: 774). Su repentina pertenencia a la nobleza es sinónimo de anacronismo social, y su propio título nobiliario "Don Hernandez" lo liga directamente con una hidalguía anclada en el pasado, vencida por la burguesía republicana que acaba de superar el Segundo Imperio de Luis Napoleón Bonaparte. El rastacuero representa, por lo tanto, una América tribal, plagada de reyes y reinas de poblados inferiores, cuya imagen está ligada en la mentalidad parisina al feudalismo de la vieja Europa medieval, enemigo del progreso de las clases medias y de la constitución progresiva de un estado del bienestar. Ejemplo de esto último es que Hernandez afirme sentirse repugnado por los periódicos europeos en los que se denuncia la explotación infantil en las fábricas, del mismo modo que critica con severidad los privilegios concedidos al reo condenado a muerte en las "naciones civilizadas". En definitiva, el indiano insertado en París constituye una construcción metonímica de la contraposición antagónica entre una Francia, definida por su emergente democracia participativa, y una América, metáfora de un anacronismo feudal. Ilustrando la ideología del momento que consagra el colonialismo como mecanismo civilizador, el personaje encarna los semas de un imperio amerindio derrotado por la victoria de las clases medias erigidas en reflejo de la soberanía popular, así como la superación de un sistema político desfasado. Encarnación del pasado aristocrático francés y de la regresión organicista de los pueblos primitivos, su regresión es tan cultural como política, confirmando así el triunfo burgués.

Es posible afirmar que el estereotipo del indiano en tanto que aborigen asilvestrado reside en un intento de multiplicar los marcadores diferenciales de éste respecto de la burguesía, con el objetivo de identificarlo y distinguirlo en la sociedad parisina independientemente de su poder adquisitivo, fomentando así la equivalencia entre "raza" y "clase social" propia del debate sociológico que domina la segunda mitad del siglo XIX ${ }^{15}$. En este sentido, el personaje cumple nuevamente con una doble función: en primer lugar, en la medida en que el indiano imita los usos culturales de la burguesía, el personaje resulta reconfortante para el espectador, ya que su actitud confirma la complaciente superioridad cultural de las naciones occidentales manifestada a través de los mecanismos civilizadores del aborigen. Hernandez se convierte, en este sentido, como tantos otros especímenes etnológicos insertados en la cultura occidental, en un trofeo humano de las virtudes civilizadoras de la expansión colonial.

No obstante, por otro lado, a pesar de que el rasero proporcionado por el poder adquisitivo homogeneiza al indiano y al burgués parisino, el rastacuero no deja de ser identificado como un extraño en el seno de la burguesía imperial. El enriquecimiento súbito en las Américas no ha borrado la carga genética, entroncando con todas las teorías fisonómicas del siglo XIX que afirmaban la posibilidad de distinguir las diferentes clases sociales -y, particularmente, al proletariado- a partir de la

15 Es éste un aspecto que caracterizó numerosas exhibiciones etnológicas en Gran Bretaña, en las que el indígena era encarnado, a falta de auténticos aborígenes, por irlandeses, esto es, por aquellos más desfavorecidos económica y socialmente en el marco del Imperio Británico. De ahí la denominación de estos últimos como "White Negroes" (Coakley, 2012: 36). 
morfología corporal. La teoría de la degeneración expuesta por Bénédict Auguste Morel en su Traité de dégénérescences physiques (1857) defendía que las "peligrosas" clases populares podían ser identificadas por sus manifestaciones de decadencia física, y que éstas eran transmitidas, e incluso intensificadas, por sus descendientes, hasta el punto de que la deficiencia inicial impedía en última instancia la reproducción de la especie, condenando así su estirpe, y evidenciando con ello la imposibilidad de escapar a un destino de impuesto por la naturaleza. La fisonomía se convertía de este modo en un diacrítico de clase. En línea con este argumento, el "rastaquouère" es un subterfugio burgués necesario para identificar visualmente, y marcar una insalvable distancia, con el "nuevo rico", a partir de un criterio de raza vinculado inexorablemente al cuerpo diferente y extraño. Su comparación y atribución de rasgos extraídos de las exhibiciones etnológicas no hace sino acentuar esa diferencia con la burguesía en la que se integra, fomentando la visualización de peculiaridades que lo devuelven a sus orígenes lejanos.

Labiche y Augier construyen así un personaje cuyo primitivismo recoge los temores de una clase social que se siente amenazada por la proliferación de "nuevos ricos" procedentes de América, sin renunciar a ridiculizar la visión que de éste posee. El indiano del vodevil es una construcción cultural de lo diferente que se consume complacientemente en su formato teatral por parte de la burguesía en tanto que recuerdo de la conquista imperial, y que connota la mirada del observador y la distancia cultural que él mismo establece respecto del objeto de observación. Con todo, el final de la obra contradice el discurso triunfalista colonial clásico que daba fe de la capacidad occidental de someter a sus usos y costumbres a los nuevos súbditos colonizados, transformando la conquista en sinónimo de progreso de civilizaciones -cuando no de auténtico "rescate" frente al primitivismo de los pueblos indígenasa manos de sus captores y redentores, y cuyo mayor exponente era el occidentalizado "Brasileño" de Meilhac y Halévy, perfectamente integrado en la "vida parisina" que daba título a la obra. Si, en estos casos, como afirma Rosemarie Garland Thomson, la explotación "se convertía en una salvación, la colonización en una conversión, y la exhibición de ésta en un testimonio de la misma" (1999: 94), el indiano de Labiche demuestra todo lo contrario, arruinando con ello el proceso de aculturamiento propio de la expansión colonial. El dramaturgo invierte esta tendencia al presentar al "rastaquouère" como un personaje transicional entre especies, indomesticable, decidido a no renunciar a su tribalismo, y que se niega a aceptar las normas del núcleo familiar decimonónico y los ritos culturales burgueses. De este modo, Labiche y Augier se sirven de él para someter a una burguesía anquilosada para la que el matrimonio no es más que una fachada social, utilizándolo como advertencia del fracaso civilizador tan unánimemente expandido y aceptado entre las clases dominantes propias de los imperios transoceánicos. En otras palabras, a diferencia de los especímenes etnológicos exhibidos en las ferias, el indiano del vodevil demuestra que no puede ser domesticado, sirviendo de amenaza a toda una sociedad en declive, como atestigua su huida final con la esposa de Martin. Convertido el Palais-Royal en el espacio para la teatralización de la ideología imperial por medio de la explotación de los prejuicios de clase existentes entre la burguesía respecto del aborigen americano, el indiano de Labiche conculca la sensación de seguridad propia de una clase basada en la identificación del otro como diferente amaestrable, representando así el fracaso del proyecto colonizador. 


\section{Referencias bibliográficas}

Bogdan, R., (1990) Freak Show. Presenting Human Oddities for Amusement and Profit. Chicago \& London, University of Chicago Press.

Brioso Santos, H., (2001) “' 'Trajisteis este animal de las Indias?': el figurón, el indiano y americano en Guárdate del agua de Calderón”, in Vega García-Luengo, G. \& I. Arellano Ayuso (dirs.), Calderón: innovación y legado. Nueva York, Peter Lang, pp. 33-51.

Brioso Santos, H., (1998) "La figura del indiano teatral en el Siglo de Oro español", in Reverte, C. \& M. de los Reyes (eds.), Actas del II Congreso Iberoamericano de Teatro. América y el teatro español del Siglo de Oro. Cádiz, Universidad, pp. 423-434.

Brunet, B., (2004) Le théâtre de boulevard. Paris, Nathan.

Coakley, J., (2012) Nationalism, Ethnicity and the State. Making \& Breaking Nations. London, Sage.

Cook, J. W., (1996) “Of Men, Missing Links, and Nondescripts: The Strange Career of P. T. Barnum's 'What is it?' Exhibition”, in Garland Thomson, R. (ed.), Freakery. Cultural Spectacles of the Extraordinary Body. New York and London, New York UP, pp 139-157.

Durbach, N., (2010) Spectacle of Deformity. Freak Shows and Modern British Culture. Berkeley, Los Angeles \& London, University of California Press.

Fahy, T., (2006) Freak Shows and the Modern American Imagination. Constructing the Damaged Body from Willa Cather to Truman Capote. Basingstoke, Palgrave Macmillan.

Fielder L., (1993) Freaks. Myths and Images of the Secret Self. New York \& London, Anchor Books.

Fielder L., (1996) Tyranny of the Normal. Essays on Bioethics, Theology \& Myth. Boston, David R. Godine.

Garland Thomson, R., (1999) "Narratives of Deviance and Delight: Staring at Julia Pastrana, the "Extraordinary Lady",, in Powell, T. (ed.), Beyond the Binary: Reconstructing Cultural Identity in a Multicultural Context. New Brunswick, NJ, Rutgers University Press, pp. 81-106.

Gobello, J., (2005) Blanqueo etimológico del lunfardo. Buenos Aires, Marcelo Héctor Oliveri editor.

Jollivet, G., (1927) Souvenirs de la vie de plaisir sous le Second Empire. Paris, Jules Tallandier.

Labiche, E., (1992 [1876]) Le prix Martin. H. Gidel. Ed. Labiche. Théâtre. Paris, Classiques Garnier. Vol. 2.

Lindfors, B., (1999) Africans on Stage. Studies in Ethnological Show Business. Bloomington \& Indianapolis, Indiana UP.

Martínez Tolentino, J., (1991) El indiano en las comedias de Lope de Vega. Kassel, Reichenberger.

Meilhac, H. \& L. Halévy, (1867) La vie parisienne. Paris, Michel Lévy.

Morel, A., (1857) Traité de dégénérescences physiques, intellectuelles et morales de l'espèce humaine. Paris, Baillière.

Pajot, S., (2003) De la femme à barbe à l'homme-canon. Phénomènes de cirque et de baraque foraine. Château d'Olonne, Orbestier.

Rothfels, N., (1996) “Aztecs, Aborigines, and Ape-People: Science and Freaks in Germany, 1850-1900", in Garland Thomson, R. (ed.), Freakery. Cultural Spectacles of the Extraordinary Body. New York and London, New York University Press, pp. 158-172.

Scholz, S., (2013) "Medical Writing and the Scientific Gaze in the Nineteenth Century: The Case of the Elephant Man", in Lembert-Heidenreich, A. \& J. Mildorf (eds), The Writing Cure: Literature and Medicine in Context. Münster, LIT Verlag, pp. 77-93. 
Smith, J., (2009) Charles Darwin and Victorian Visual Culture. Cambridge, Cambridge UP. Strother, Z. S., (1999) "Display of the Body Hottentot", in Lindfors, B. (ed.), Africans on Stage. Studies in Ethnological Show Business. Bloomington \& Indianapolis, Indiana UP, pp. 1-61. 